\title{
Tenure bubbles burst
}

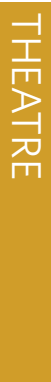

On 24 September 2012, Amy Bishop was sentenced to life in prison without parole for the murder and attempted murder of her colleagues at the University of Alabama in Huntsville. In 2009, Bishop had been denied tenure and, aged 44 , had completed her last semester under contract at the university. The following year she took part in a departmental meeting and closed proceedings by shooting several of her colleagues at close range with a 9-millimetre handgun.

Just days before the sentencing, playwright and chemist Carl Djerassi's Insufficiency commenced a four-week stint in London under the direction of Andy Jordan. Although nowhere near as dark as the Bishop saga, the play, whose action alternates between courtroom and laboratory, ruminates on the pressures of academia and the emotionally charged process of securing tenure.

The play tells the story of Jerzy Krzyz, on trial for the murder of his colleagues, following their refusal to grant him tenure. The prosecution's case hangs on motive alone: the cause of death remains unclear, but the jury (or audience) is led to believe that it had something to do with an experimental champagne crafted by the defendant.

A specialist in the somewhat marginal science of bubbles, Jerzy, we learn, had left his native Poland at the age of 39 to take up a non-tenured post at an American university. He is keen to secure tenure quickly especially because this was, he claims, promised by the Provost when he made the move. But his request for an expedited tenure hearing after four years is met with resistance from the faculty, ultimately resulting in 17 of the 26 members voting against him.

The perception that he is queue-jumping is clearly not the only reason for the faculty's resistance. Despite his affable manner, Jerzy Krzyz has some pretty serious character flaws. $\mathrm{He}$ is suspicious of his colleagues (whom he insists on dubbing "those jerks"), requiring that they sign confidentiality agreements before assessing his research. His suspicion is fuelled by a (not unreasonable) conviction that they are jealous of his commercial funding - primarily from Dom Pérignon. But this funding also affects his academic output: he refuses to publish his research in peer-reviewed journals on the premise that it may interfere with his funding. He is also,

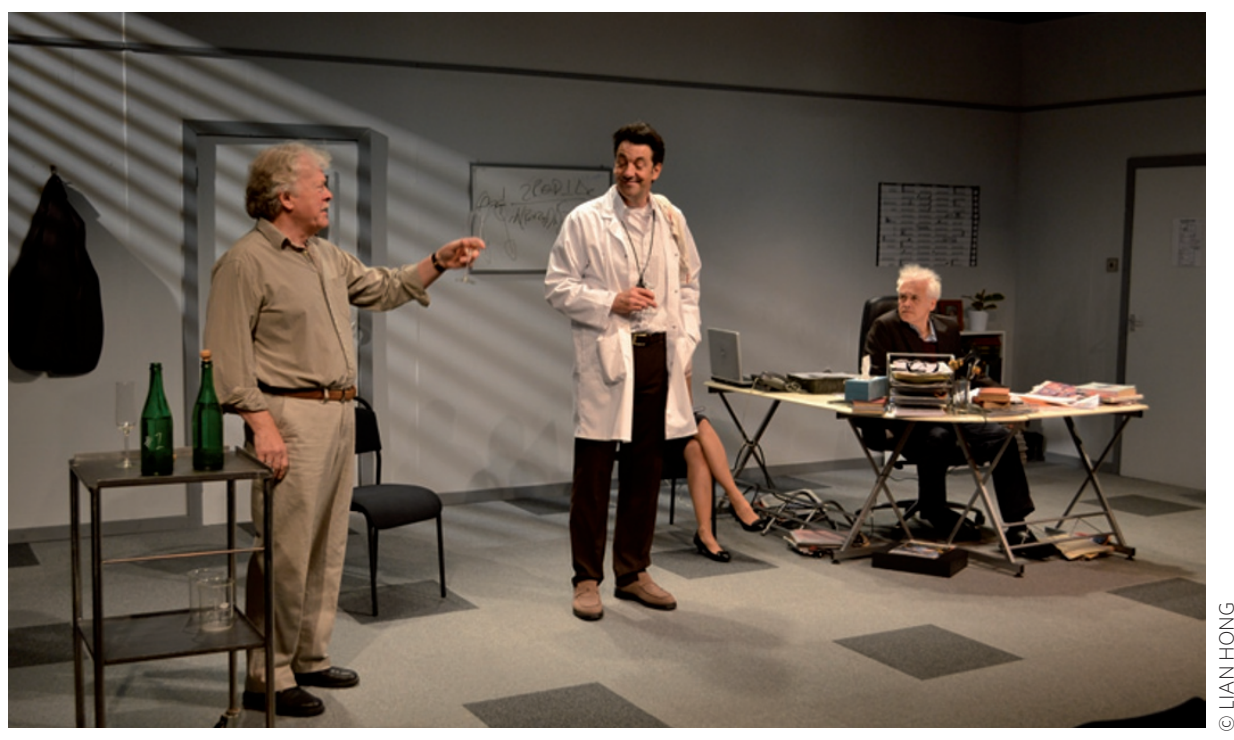

perhaps admirably, averse to the kind of 'salami slicing' perpetrated by his colleagues.

But his reluctance to publish also betrays a kind of self-delusion: when asked why he won't submit a more fundamental discovery for publication, he answers, "Because it would get accepted immediately. It's that good!"

Other work is drafted without references, and Jerzy cites Einstein's 1905 paper as a precedent when questioned about the omission.

He makes an exception for his work on the bitterness of beer foam, publishing in the Beer Drinker's Quarterly - a decision that both angers his department chair, and lands Jerzy an appearance on the BBC. The opportunity grants him a lesson in levity from a producer who inspires Jerzy to take a different approach to his colleagues, ultimately landing him in the mess in which we find him.

For a scientist, particularly one now outside the laboratory, it is a treat to see this world portrayed with such astounding attention to detail. Tim Dutton's performance as the disgruntled Professor Krzyz does not miss a beat, affecting a tone and manner so familiar it borders on eerie. The department chair, Leo Bramble, on the other hand, is somewhat confusingly portrayed as a bumbling bureaucrat who gets frustrated by an equation expressing a rate as inverse time. This aversion to scientific discussion strikes an off-chord in an otherwise excellent character study - one that serves to shine a light on Jerzy's problematic personality.

Because as much as Djerassi would have us side with the lovable, if pompous, professor, it is through his interactions with
Leo and his secretary Steffi (who doubles as Jerzy's secret lover) that we recognize the reasons for his inability to secure tenure as well as the probable cause of the crime of which he is accused.

In one of the play's opening scenes, Jerzy demonstrates that salt steeped in soda seeds nucleation, flooding Leo's desk in the process. Herein lies the science at the heart of the play's plot: Jerzy has synthesized nanoparticles embedded in a polymer whose rate of dissolution results in delayed gas release $-\mathrm{a}$ solution to the problem of flat champagne. The industrial implications are clear, but Jerzy realizes that delayed bubble release might also effect a humorous response, and his lesson in levity inspires an ill-fated practical joke on those responsible for his denial of tenure.

The play is ultimately a light and fairly frothy attempt to tease out some of the idiosyncrasies of academic life, trading the darker themes it might have addressed for cheap, if well-intentioned, laughs. Despite this, Djerassi's work succeeds in capturing some of the more problematic aspects of academia. Through Jerzy's conversations with Steffi and Leo, we learn that the tenure decision may have resulted from his English being "too Polish" - an admission that would surely be cause for some legal concern in today's American university system, but one suggestive of the complex cultural issues involved in the pursuit of tenure.

\section{REVIEWED BY ABIGAIL KLOPPER}

Abigail Klopper is an Associate Editor at Nature Physics. 